\title{
Serum CEA Level Normal
}

National Cancer Institute

\section{Source}

National Cancer Institute. Serum CEA Leve/ Normal. NCI Thesaurus. Code C162045.

The amount of carcinoembryonic antigen present in a serum sample is normal. 